\title{
SEVEN SPECIES OF FRESHWATER LICHEN-FORMING FUNGI NEWLY RECORDED FROM POLAND
}

\author{
Natalia Matura ${ }^{1}$, Beata Krzewicka \& Adam Flakus
}

\begin{abstract}
This paper presents seven freshwater lichen species from Western Carpathian streams: Bryobilimbia ahlesii (Körb.) Fryday et al., Rhizocarpon sublavatum Fryday, Thelidium circumspersellum (Nyl.) Zschacke, T. klementii Servít, T. pluvium Orange, T. rehmii Zschacke and Verrucaria devensis (G. Salisbury) Orange. All of them are first records for Poland. Thelidium klementii is new for the Carpathians and was previously known only from the type locality in Germany. Morphological descriptions based on Polish specimens are presented, and the ecology and geographical distribution of these lichens are briefly discussed.
\end{abstract}

Key words: amphibious lichens, biodiversity, Carpathians, distribution, lichenized fungi, new records

Natalia Matura, Beata Krzewicka \& Adam Flakus, Department of Lichenology, W. Szafer Institute of Botany, Polish Academy of Sciences, Lubicz 46, 31-512 Kraków, Poland; e-mails: n.kapek@botany.pl,b.krzewicka@botany.pl, a.flakus@botany.pl

\section{INTRODUCTION}

The vast majority of lichens are restricted to terrestrial environments and their thalli do not tolerate long periods of submersion, but there is a small group of lichens whose proper development depends on constant or recurrent inundation (Thüs et al. 2014). These freshwater (amphibious) lichens are a widely distributed but still insufficiently studied component of freshwater habitats. Among the 1642 species of lichens known from Poland (Fałtynowicz \& Kossowska 2016) only 56 are freshwater lichens. This paper reports seven freshwater lichen species newly recorded from the Western Carpathians in Poland.

\section{Material AND METHODS}

The study is based on material collected by the first author during field work in 2012-2016 for research focused on the lichen biota of freshwater habitats in the Polish Western Carpathians. The lichen material was analyzed by standard morphological and anatomical methods using Nikon SMZ 800N and Nikon Eclipse E200 microscopes. The pigments Atra-brown (sensu Meyer \& Printzen 2000) and Macrocarpa-green (sensu Fryday 2002) were identified. Lichen substances were

\footnotetext{
1 Corresponding author
}

studied by thin-layer chromatography (TLC) using the methods described by Orange et al. (2001). Voucher specimens are in the herbarium of the W. Szafer Institute of Botany, Polish Academy of Sciences (KRAM).

\section{RESULTS AND DISCUSSION}

Bryobilimbia ahlesii (Körb.) Fryday, Printzen \& S. Ekman

Thallus thin, continuous or irregularly rimose, pale grey or grey-green. Apothecia $0.45-0.6 \mathrm{~mm}$ diam., sessile. Disc reddish-brown to brown-black, concave to slightly convex. Apothecial margin usually prominent and persistent. Exciple dark reddish brown in section at outer edge and almost colorless to pale reddish brown in inner part. Epihymenium colorless or yellowish brown to pale reddishbrown, $\mathrm{K}-$. Hymenium colorless, 60-80 $\mu \mathrm{m}$ high, often with scattered blue-violet $(\mathrm{K}+$ green) granules. Hypothecium brown to brownish black, usually with blue-violet $(\mathrm{K}+$ green) granules. Asci Porpidia-type. Ascospores simple, colorless, ellipsoid, $12-16(-17.5) \times(4-) 5-6 \mu \mathrm{m}$, with or without gelatinous coat.

Chemistry: lichen substances not detected by TLC; thallus $\mathrm{K}-, \mathrm{C}-, \mathrm{KC}-, \mathrm{Pd}-$. 
Notes. The new generic name Bryobilimbia was proposed by Fryday et al. (2014) for Lecidea hypnorum and its closely related taxa. Bryobilimbia can be distinguished from Lecidea and Mycobilimbia by its Porpidia-type ascus. It differs from Clauzadea and Porpidia in having ascospores with a finely warted perispore and/or thin gelatinous coat, whereas Porpidia has ascospores with a well-developed gelatinous coat and Clauzadea has ascospores with only a thin gelatinous coat when young. Bryobilimbia is also distinguished by the presence of scattered blueviolet $(\mathrm{K}+$ green) granules in the hymenium, and mostly simple paraphyses. It differs from Lecidoma and Romjularia in having a thinner, membranaceous thallus and darker hypothecium. Both Bryobilimbia ahlesii and Bryobilimbia sanguineoatra (Wulfen) Fryday, Printzen \& S. Ekman grow on rocks and thus can be easily confused, but the latter differs in having a pale yellow thallus and smaller ascospores [(9-)11-14 × 3.5-5(-6) $\mu \mathrm{m}]$ (Fryday et al. 2014; Hu et al. 2014).

Bryobilimbia ahlesii occurs at shaded sites with high air humidity, where it grows usually on siliceous rocks. It is a typical riparian species which usually occurs in the upper splash water zone but avoids long periods of inundation. In the study area this species was found on damp sandstone on the bank of Młodowski Potok stream in the Beskid Sądecki Mts.

It is a rather rare species, known from scattered localities throughout Europe (Czech Republic, Finland, Germany, Great Britain, Lithuania, Russia, Sweden), North America (USA) and Asia (China) (Arup 2004; Coppins \& Fryday 2006; Urbanavichus 2010; Halda et al. 2011; Fryday et al. 2014; Hu et al. 2014; Motiejūnaitė \& Grochowski 2014; Paukov et al. 2017).

SPecimen eXamined. Poland. Beskid SĄDECKi mts: Pasmo Radziejowej range, Młodowski Potok stream, above forest road, on damp sandstone, $49^{\circ} 27^{\prime} 3^{\prime \prime} \mathrm{N}$, $20^{\circ} 40^{\prime} 33^{\prime \prime}$ E, 526 m, 12 June 2014, N. Matura (KRAM L-69161).

\section{Rhizocarpon sublavatum Fryday}

Thallus thin, cracked and areolate, grey or brown. Prothallus usually distinct and black. Apothecia flat, epruinose. Disc black, 0,3-0,5(-0.6) mm in diam., irregularly arranged, innate when young, becoming sessile when mature. Apothecial margin thin, the same color as disc. Exciple brownish in section (Atra-brown pigment), $\mathrm{K}$ - or $\mathrm{K}+$ intensifying, $\mathrm{N}$ and $\mathrm{HCl} \pm$ intensifying, sometimes with Macrocarpa-green $(\mathrm{K}-, \mathrm{N}+$ red, $\mathrm{HCl}+$ bright blue) patch in upper part. Epihymenium olive-green to olive-brown (Atra-brown and Macrocarpa-green pigments intermixed). Hymenium colorless, I+ blue, 120-140 $\mu \mathrm{m}$ high. Hypothecium medium brown to dark brown. Asci 8-spored, Rhizocarpontype. Ascospores muriform, colorless, occasionally almost black when mature, narrowly ellipsoid to ellipsoid, $17-38 \times 11-25 \mu \mathrm{m}$.

Chemistry: lichen substances not detected by TLC; thallus $\mathrm{K}-, \mathrm{C}-, \mathrm{KC}-, \mathrm{Pd}-$.

Notes. Rhizocarpon sublavatum can be confused with several species of the genus on account of its hyaline and muriform ascospores. The most similar species is R. lavatum (Fr.) Hazsl., which differs from $R$. sublavatum in having a paler thallus and larger and narrower ascospores (34-44 $\times$ 14-18 $\mu \mathrm{m})$. Rhizocarpon reductum Th. Fr. differs in the presence of stictic acid in the thallus and apothecia, which give spot test reactions $\mathrm{K}+$ yellow and $\mathrm{Pd}+$ orange. Rhizocarpon anaperum (Vain.) Vain. has a darker Macrocarpa-green pigment in the epihymenium and browner and slightly convex areoles, whereas $R$. sublavatum has flat areoles (Ihlen 2004).

Rhizocarpon sublavatum grows mostly on siliceous rocks in damp places. It prefers moderately shady habitats. In the study area this species was found at two localities in the Polish Tatra Mts, on temporarily inundated and splashed siliceous rocks.

This species is widely distributed in Great Britain, Norway, Sweden, Finland and Austria (Fryday 1996, 2000; Ihlen 2004; Berger \& Priemetzhofer 2014).

Specimens examined. Poland. Tatry mts: High Tatra Mts, black hiking trail from Murowaniec mountain shelter to Świnicka Przełęcz pass, Litworowy Staw Lake, on temporarily inundated siliceous rock, $49^{\circ} 13^{\prime} 54^{\prime \prime} \mathrm{N}, 19^{\circ} 59^{\prime} 49^{\prime \prime} \mathrm{E}, 1586$ m, 20 July 2015, N. Matura (KRAM L-69162); Biały Żleb gully, blue hiking trail from Morskie Oko lake to Dolina Pięciu Stawów Polskich valley, small stream near trail, on splashed 
siliceous rock, $49^{\circ} 12^{\prime} 39^{\prime \prime} \mathrm{N}, 20^{\circ} 4^{\prime} 8^{\prime \prime} \mathrm{E}, 1568 \mathrm{~m}, 19$ July 2015, N. Matura (KRAM L-69163).

\section{Thelidium circumspersellum (Nyl.) Zschacke}

Thallus inconspicuous, very thin to vanishing, brown, without cortex. Photobiont chlorococcoid alga, 3-6 $\mu \mathrm{m}$ in diam., arranged in small groups or irregularly dispersed. Perithecia sessile to semi-immersed. Involucrellum absent. Exciple black-brown, reaching up to $200 \mu \mathrm{m}$ in diam. Asci 8-spored, 64-75 × 17-25 $\mu \mathrm{m}$. Ascospores 3-septate, colorless, $18-27 \times 7-10 \mu \mathrm{m}$.

Chemistry: lichen substances not studied by TLC; thallus $\mathrm{K}-, \mathrm{C}-, \mathrm{KC}-, \mathrm{Pd}-$.

Notes. Thelidium circumspersellum is very similar to T. zwackhii (Hepp) A. Massal.; basically $T$. zwackhii can be distinguished by its thicker thallus, larger asci $(90-120 \times 29-40 \mu \mathrm{m})$, larger ascospores $(20-36 \times 9-15 \mu \mathrm{m})$ and transparent exciple in its lower part (Thüs \& Schultz 2009). The two species are very similar in morphology and are sometimes difficult to determine. It may be a complex of species or one species with high phenotypic variation. Further molecular analysis will help in determining their relationship.

This species occurs on periodically inundated limestone. It prefers moderately shady habitats. During this study, Thelidium circumspersellum was found at a single locality in Uhryński Potok stream in the Beskid Sądecki Mts on a frequently inundated rock.

Previously this species was reported from Romania (Thüs \& Nascimbene 2008) and Austria (Berger \& Priemetzhofer 2014; Hafellner \& Türk 2016).

Specimen examined. Poland. Beskid Sądecki MTs: Pasmo Jaworzyny Krynickiej range, Uhryński Potok stream, lower part of Uhryń village, near nature trail, on limestone rock often inundated, $49^{\circ} 29^{\prime} 44^{\prime \prime} \mathrm{N}$, $20^{\circ} 51^{\prime} 38^{\prime \prime}$ E, 576 m, 24 Aug. 2013, N. Matura (KRAM L-69166).

\section{Thelidium klementii Servít}

Thallus semi-endolithic, rather thick (120$230 \mu \mathrm{m})$, finely rimose to areolate, predominantly whitish grey; cortex colorless. Photobiont coccoid green alga, 4-9 $\mu \mathrm{m}$ in diam., dispersed.
Perithecia semi-immersed in thallus, naked. Involucrellum apical or absent. Exciple dark brown, up to $c a 200 \mu \mathrm{m}$ in diam. Asci 8-spored, 70-80× 25-28 $\mu \mathrm{m}$. Ascospores mostly (0-)1-septate, colorless, $17-30 \times 10-15 \mu \mathrm{m}$.

Chemistry: lichen substances not studied by TLC; thallus $\mathrm{K}-, \mathrm{C}-, \mathrm{KC}-, \mathrm{Pd}-$.

Notes. Thelidium rivulicolum (Nyl.) Migula is similar in having a thick thallus and 1-septate ascospores, but differs in having an almost twicelarger exciple (300-450 $\mu \mathrm{m}$ diam.) and slightly longer asci $(90 \times 30 \mu \mathrm{m})$ and ascospores $(23-42$ $\times 7-15 \mu \mathrm{m})$ (Thüs \& Schultz 2009).

Thelidium klementii occurs on temporarily inundated calcareous rocks with high content of silica (Thüs \& Schultz 2009). During this study it was collected from submerged and splashed sandstone rocks. It prefers moderately shaded habitats. In the study area this species was recorded at a few localities in the Beskid Sacdecki Mts and at one locality in the Beskid Żywiecki Mts.

Outside Poland, Thelidium klementii is known only from the type locality in Germany which was destroyed when a large reservoir was constructed, and the species is now threatened with extinction (Thüs \& Nascimbene 2008).

Specimens examined. Poland. Beskid Sądecki MTS: Pasmo Jaworzyny Krynickiej range, Baraniecki stream, upper part of stream, in forest, on submerged sandstone rock, $49^{\circ} 24^{\prime} 20^{\prime \prime} \mathrm{N}, 20^{\circ} 48^{\prime} 16^{\prime \prime} \mathrm{E}, 750 \mathrm{~m}, 2$ July 2013, N. Matura (KRAM L-69165); Pasmo Radziejowej range, Potok Bliszcze stream, near site of tree-felling and human settlements, on splashed sandstone rock, $49^{\circ} 29^{\prime} 17^{\prime \prime} \mathrm{N}, 20^{\circ} 25^{\prime} 24^{\prime \prime} \mathrm{E}, 415 \mathrm{~m}, 5$ June 2014, N. Matura (KRAM L-69167); Góry Leluchowskie Mts, Wojkowski Potok stream, behind asphalt road, near clearing and forest in upper part of Wojkowa village, on splashed sandstone rock, $49^{\circ} 20^{\prime} 13^{\prime \prime} \mathrm{N}, 20^{\circ} 59^{\prime} 22^{\prime \prime} \mathrm{E}, 689 \mathrm{~m}$, 4 Sept. 2013, N. Matura (KRAM L-69168); BESKID ŻYwIECKI MTs: Danielka stream, near mountain shelter, on submerged sandstone rock, $49^{\circ} 28^{\prime} 29^{\prime \prime} \mathrm{N}, 19^{\circ} 7^{\prime} 37^{\prime \prime} \mathrm{E}, 620 \mathrm{~m}$, 1 Aug. 2015, N. Matura (KRAM L-69164).

\section{Thelidium pluvium Orange}

Thallus epilithic, thin to moderately thick (35-85 $\mu \mathrm{m})$, continuous or slightly cracked, greyish, brown or greenish. Photobiont coccoid 
green alga, reaching up to $8 \mu \mathrm{m}$ in diam. Perithecia immersed in prominent thallus warts, $250-450 \mu \mathrm{m}$ in diam. Involucrellum thin (up to $30 \mu \mathrm{m}$ ), apical to reaching thallus base, often laterally spreading, leaving transparent area between exciple and involucrellum, \pm covered by layer of thallus. Exciple $100-320 \mu \mathrm{m}$ in diam. Asci 8-spored, 75-100 $\times$ 25-35 $\mu \mathrm{m}$. Ascospores 1-septate, colorless, 19-36 $\times 8-17 \mu \mathrm{m}$.

Chemistry: lichen substances not studied by TLC; thallus $\mathrm{K}-, \mathrm{C}-, \mathrm{KC}-, \mathrm{Pd}-$.

Notes. Thelidium pluvium is similar to T. methorium (Nyl.) Hellb., which differs in having larger perithecia $(0.43-1.60 \mathrm{~mm}$ in diam.) which are usually not covered by a thallus layer, larger ascospores $(24-46 \times 13-21 \mu \mathrm{m})$ and a well-developed, thicker involucrellum. Thelidium minutulum Körb. is also similar but it has an apical involucrellum (or none) and smaller ascospores (13-32 $\times$ 4-15 $\mu \mathrm{m}$ ) than T. pluvium (Thüs \& Schultz 2009).

Thelidium pluvium occurs on temporarily inundated or splashed siliceous rocks. It prefers shady habitats. During this study it was found at a single locality in Potok Rusnaków stream in the Beskid Makowski Mts on a small splashed stone at a moderately sunny site.

This species was previously known from a few scattered localities. Probably it is mistaken in the field for Verrucaria hydrophila Orange. It has been reported from mountain regions in Central European mountains (Germany and Austria), Northern Europe (Norway) and the British Isles (UK) (Orange 1991; Wirth 1999; Berger \& Priemetzhofer 2000; Keller 2000; Cezanne et al. 2008; Thüs \& Nascimbene 2008). Outside Europe it was found in Tasmania (McCarthy 1994).

Specimen examined. Poland. Beskid Makowski MTS: Potok Rusnaków stream, in forest, on splashed siliceous stone, $49^{\circ} 45^{\prime} 41^{\prime \prime} \mathrm{N}, 19^{\circ} 54^{\prime} 25^{\prime \prime} \mathrm{E}, 585 \mathrm{~m}$, 8 July 2014, N. Matura (KRAM L-69172).

\section{Thelidium rehmii Zschacke}

Thallus thin to moderately thick, $15-110 \mu \mathrm{m}$, slightly cracked, greenish grey. Photobiont chlorococcoid alga, 3-10 $\mu \mathrm{m}$ in diam., irregularly arranged in thallus. Perithecia semi-immersed in thallus to almost sessile. Involucrellum absent or apical but never laterally spreading. Exciple 200-300 $\mu \mathrm{m}$ in diam. Asci 8-spored, 67-93 $\times$ 26-40 $\mu \mathrm{m}$. Ascospores 1-septate, colorless, 19-30 $\times 8-15 \mu \mathrm{m}$.

Chemistry: lichen substances not studied by TLC; thallus $\mathrm{K}-, \mathrm{C}-, \mathrm{KC}-, \mathrm{Pd}-$.

Notes. Thelidium rehmii can be easily confused with $T$. minutulum on account of their very similar morphology, but T. minutulum appears to be restricted to calcareous or basic siliceous rocks (limestone, metamorphic rocks) and its photobiont cells are arranged in distinct groups (Thüs \& Schultz 2009).

Thelidium rehmii grows on temporarily inundated and splashed siliceous rocks in the vicinity of streams. It prefers more or less shaded places. In the study area it was found at scattered localities.

In Europe this species is known from a few localities in southern Germany (Thüs \& Nascimbene 2008) and the Czech Republic (Servít 1954). Recently it was also found in Japan (Harada 2013).

Specimens examined. Poland. Beskid Makowski MTS: Potok Rusnaków stream, in forest, below forest road, on rock often inundated, $49^{\circ} 45^{\prime} 41^{\prime \prime} \mathrm{N}, 19^{\circ} 54^{\prime} 25^{\prime \prime} \mathrm{E}$, 585 m, 8 July 2014, N. Matura (KRAM L-69171); BESKID NISKI MTS: Bielcza stream, near clearing and entrance to Kamień Reserve, on stone often inundated, $49^{\circ} 23^{\prime} 34^{\prime \prime} \mathrm{N}, 21^{\circ} 47^{\prime} 55^{\prime \prime} \mathrm{E}, 577 \mathrm{~m}, 14$ Aug. 2015, N. Matura (KRAM L-69178); BeSKID SĄDECKI MTS: Pasmo Jaworzyny Krynickiej range, Baraniecki stream, upper part of stream, in forest, on splashed rock, $49^{\circ} 24^{\prime} 20^{\prime \prime} \mathrm{N}$, $20^{\circ} 48^{\prime} 16^{\prime \prime} \mathrm{E}, 750 \mathrm{~m}, 2$ July 2013, N. Matura (KRAM L-69182); Szczawniczek stream, near road, among human settlements, on splashed rock, $49^{\circ} 23^{\prime} 14^{\prime \prime} \mathrm{N}$, 20 53'6"E, 597 m, 10 Sept. 2013, N. Matura (KRAM L-69170); Uhryński Potok stream, middle part of Uhryń village, open habitat near road, bridge and human settlements, on temporarily inundated rock, $49^{\circ} 28^{\prime} 36^{\prime \prime} \mathrm{N}$, 2051'35"E, 641 m, 23 Aug. 2013, N. Matura (KRAM L-69175); Uhryński Potok stream, lower part of Uhryń village, near nature trail, on splashed stone, $49^{\circ} 29^{\prime} 44^{\prime \prime} \mathrm{N}$, 2051'38'E, 576 m, 24 Aug. 2013, N. Matura (KRAM L-69173); Pasmo Radziejowej range, Kozłecki stream, in forest, above human settlements, on splashed rock, $49^{\circ} 27^{\prime} 27^{\prime \prime} \mathrm{N}, 20^{\circ} 27^{\prime} 39^{\prime \prime} \mathrm{E}, 663 \mathrm{~m}, 30$ May 2014, N. Matura (KRAM L-69179); Przysietnica stream, along road between bridge and small dam, near chapel, on splashed 
rock, 49 $28^{\prime} 45^{\prime \prime} \mathrm{N}, 20^{\circ} 34^{\prime} 31^{\prime \prime} \mathrm{E}, 816 \mathrm{~m}, 5$ June 2014, N. Matura (KRAM L-69183); GoRCE MTS: Lubański stream, behind last house on road, below road, on rock often inundated, $49^{\circ} 30^{\prime} 34^{\prime \prime} \mathrm{N}, 20^{\circ} 20^{\prime} 16^{\prime \prime} \mathrm{E}, 621 \mathrm{~m}$, 30 Aug. 2015, N. Matura (KRAM L-69181); PIENINY MTs: Zagórny Potok stream, near human settlements, on rocks often inundated and splashed, $49^{\circ} 24^{\prime} 19^{\prime \prime} \mathrm{N}$, $20^{\circ} 21^{\prime} 57^{\prime \prime}$ E, 520 m, 9 Sept. 2015, N. Matura (KRAM L-69176).

\section{Verrucaria devensis (G. Salisbury) Orange}

Thallus superficial, 40-140 $\mu \mathrm{m}$ thick, pale grey-green to greyish brown or medium brown, smooth, almost subgelatinous, continuous or usually locally or extensively cracked (cracks partially or sometimes completely delimiting areoles); black basal layer either locally or extensively present. Prothallus white. Perithecia immersed in thallus, forming very low projections. Involucrellum conical at first, then becoming very wide-spreading and confluent in between. Exciple colorless, 120 $210 \mu \mathrm{m}$ in diam. Asci 8 -spored. Ascospores simple, colorless, oblong ellipsoid, (16-)18-23 × 8-10 $\mu \mathrm{m}$.

Chemistry: lichen substances not studied by TLC; thallus $\mathrm{K}-, \mathrm{C}-, \mathrm{KC}-, \mathrm{Pd}-$.

Notes. Verrucaria devensis was recently described by Orange (2014). It can be easily confused with $V$. praetermissa (Trevisan) Anzi, but $V$. devensis differs in having a strongly pigmented, thinner and almost subgelatinous thallus. Another similar species, $V$. elaeina Borrer, can be distinguished from $V$. devensis because the former lacks a black basal thalline layer and has a weakly developed involucrellum, more exposed perithecia, and paler, non-gelatinous thallus.

Verrucaria devensis occurs on inundated rocks and stones in shady and sunny habitats. During this study it was found at a few localities.

Outside Poland, Verrucaria devensis has been reported only from Wales and Scotland so far (Orange 2014).

Specimens examined. Poland. Beskid Makowski MTs: Rusnaków stream, near human settlements, on submerged rock, $49^{\circ} 44^{\prime} 35^{\prime \prime} \mathrm{N}, 1^{\circ} 54^{\prime} 39^{\prime \prime} \mathrm{E}, 407 \mathrm{~m}, 9$ July 2014, N. Matura (KRAM L-69174); BesKID MaLY MTS: Zebrutnica stream, in forest, by roadside, on submerged rock, $49^{\circ} 46^{\prime} 8^{\prime \prime} \mathrm{N}, 19^{\circ} 25^{\prime} 44^{\prime \prime} \mathrm{E}, 569 \mathrm{~m}, 5$ July
2014, N. Matura (KRAM L-69177); BESKID SĄDECKI MTs: Pasmo Radziejowej range, Przysietnica stream, along forest road, below bridge, on submerged stone, $49^{\circ} 29^{\prime} 9^{\prime \prime} \mathrm{N}, 20^{\circ} 34^{\prime} 33^{\prime \prime} \mathrm{E}, 712 \mathrm{~m}, 6$ June 2014, N. Matura (KRAM L-69180); Góry Leluchowskie Mts, Wojkowski Potok stream, lower part of Wojkowa village, open habitat near road, on submerged stone, $49^{\circ} 21^{\prime} 48^{\prime \prime} \mathrm{N}$, 20 58'56"E, 555 m, 4 Sept. 2013, N. Matura (KRAM L-69169).

Acknowledgements. We are grateful to Professor Martin Kukwa and the anonymous reviewer for helpful remarks and suggestions on the manuscript. The study was supported by the statutory fund of the W. Szafer Institute of Botany, Polish Academy of Sciences, and by the Polish Ministry of Science and Higher Education through its Program for Young Scientists and Doctoral Studies Participants under grants for the first author.

\section{REFERENCES}

ARUP U. 2004. Three overlooked Lecidea species in Sweden. Symb. Bot. Upsal. 34(1): 39-48.

Berger F. \& Priemetzhofer F. 2000. Neueundseltene Flechten und lichenicole Pilze aus Oberösterreich, Österreich III. Herzogia 14: 59-84.

Berger F. \& Priemetzhofer F. 2014: Erläuterungen und Erstnachweise von Flechten in Oberösterreich, sowie weitere erwähnenswerte Beobachtungen. 1. Update des Flechtenatlas. Stapfia 101: 53-65.

Cezanne R., Eichler M., Hohman M. L. \& Wirth V. 2008. Die Flechten des Odenwaldes. Andrias 17: 1-520.

Coppins B. J. \& Fryday A. 2006. Reassessment of some lichen species described by Josiah Lowe, and notes on some other North American lecideoid lichens. Bryologist 109(1): 9-17.

Faltynowicz W. \& KossowsKa M. 2016. The lichens of Poland. A fourth checklist. Acta Botanica Silesiaca, Monographiae 8: 3-122.

FRYDAY A. 1996. The lichen vegetation of some previously overlooked high-level habitats in North Wales. Lichenologist 28(6): 521-541.

FrYdAY A. 2000. On Rhizocarpon obscuratum (Ach.) Massal., with notes on some related species in the British Isles. Lichenologist 32(3): 207-224.

FrYDAY A. 2002. A revision of the species of the Rhizocarpon hochstetteri group occurring in the British Isles. Lichenologist 34: 451-477.

Fryday A. \& Printzen Ch. \& Ekman S. 2014. Bryobilimbia, a new generic name for Lecidea hypnorum and closely related species. Lichenologist 46(1): 25-37.

HAFEllner J. \& TÜRK R. 2016. Die lichenisierten Pilze Österreichs - eine neue Checkliste der bisher nachgewiesenen 
Taxa mit Angaben zu Verbreitung und Substratökologie. Stapfia 104(1): 2-216.

Halda J. P., Bouda F., Fessová A., Kocourková J., MalǐčeK J., Müller A., Peksa O., Svoboda D., Šoun J. \& VONDRÁK J. 2011. Lichens recorded during the autumnal bryo-lichenological meeting in Železné hory Mts (Czech Republic), September 2009. Bryonora 47: 40-51.

Harada H. 2013. The lichen genus Thelidium (Verrucariaceae) in Japan. Lichenology 11(2): 53-66.

Hu L., Zhao X., Sun L. Y., Zhao Z. T. \& Zhang L. L. 2014. Four lecideoid lichens new to China. Mycotaxon 128: 83-91.

IHLEN P. G. 2004. Taxonomy of the non-yellow species of Rhizocarpon (Rhizocarpaceae, lichenized Ascomycota) in the Nordic countries, with hyaline and muriform ascospores. Mycol. Res. 108: 533-570.

Keller C. 2000. Die Wasserflechten der Teigitsch zwischen der Langmannsperre und dem Kraftwerk Arnstein (Steiermark, Österreich). Herzogia 14: 49-58.

MCCARTHY P. M. 1994. Additional lichen records for Australia 19. Austral. Lichen. Newslett. 35: 17.

Meyer B. \& Printzen C. 2000. Proposal for a standardized nomenclature and characterization of insoluble lichen pigments. Lichenologist 32: 571-583.

Motiejūnaité J. \& Grochowski P. 2014. Miscellaneous new records of lichens and lichenicolous fungi. Herzogia 27(1): 193-198.

OrAnge A. 1991. Thelidium pluvium (Verrucariales), a new lichenized species from north-west Europe. Lichenologist 23: 99-106.

Orange A. 2014. Two new or misunderstood species related to Verrucaria praetermissa (Verrucariaceae, lichenized Ascomycota). Lichenologist 46(5): 605-615.
Orange A., James P. W. \& White F. J. 2001. Microchemical Methods for the Identification of Lichens. British Lichen Society, London.

Paukov A. G., Gagarina L. V. \& Frolov I. V. 2017. New and interesting lichen records from the Ural Mountains, Russia. Folia Cryptog. Estonica 54: 25-30.

SERvìt M. 1954. Československé lišejniky celedi Verrucariaceae. Nakladatelstvi Československé Akademie Věd, Praha.

Smith C. W., Aptroot A., Coppins B. J., Fletcher A., GilBert O. L., James P. W. \& Wolseley P. A. (eds) 2009. The Lichens of Great Britain and Ireland. British Lichen Society, London.

Thüs H. \& NASCIMBENE J. 2008. Contributions toward a new taxonomy of central European freshwater species of the lichen genus Thelidium (Verrucariales/Ascomycota). Lichenologist 40: 499-521.

THüs H. \& Schultz M. 2009. Süsswasserflora von Mitteleuropa - Freshwater Flora of Central Europe). In: B. BÜDEL, G. GÄrtner, L. Krienitz, H.-R. Preisig \& M. SchagerL (eds), Fungi, Lichens 1: 1-223. Spektrum Akademischer Verlag, Heidelberg.

Thüs H., Aptroot A. \& Seaward M. R. D. 2014. Freshwater fungi and fungal-like organisms. In: E. B. G. JONES, K. D. HydE \& K.-L. PANG (eds), Freshwater fungi, pp. 335-358. Walter de Gruyter GmbH, Boston.

Urbanavichus G. 2010. A checklist of the lichen flora of Russia. Nauka, St. Petersburg.

WIRTH V. 1999. Neu- und Wiederfunde von Flechten und flechtenbewohnenden Pilzen in Deutschland. Jahresh. Vereins Vaterl. Naturk. Württemberg 155: 227-236. 